\title{
Stimulation by Octanoate of Insulin Release from Isolated Rat Pancreas
}

\author{
By Shafeek S. Sanbar and Julio M. Martin
}

Using pieces of rat pancreas incubated in Krebs-bicarbonate buffer containing $0.6 \mathrm{mg}$. glucose $/ \mathrm{ml}$., it has been found that addition of $3.0 \mathrm{mM}$. octanoate to the incubation medium significantly ( $p$ $<.001$ ) increased insulin release above control levels by $4.94 \pm 0.89 \mu \mathrm{U}$. insu$\mathrm{lin} / \mathrm{mg}$. of pancreatic tissue. Increasing the glucose concentration in the incu- bation medium to $3.0 \mathrm{mg} . / \mathrm{ml}$. without addition of octanoate produced a slightly smaller though significant $(p<.05)$ increase in insulin release $(2.96 \pm 0.96$ $\mu \mathrm{U} . / \mathrm{mg}$.) above control levels. In conclusion, octanoate is capable of directly stimulating additional release of insulin by the beta-cells of the pancreas. (Metabolism 16: No. 5, May, 482-484, 1967)

$\mathbf{R}^{\mathrm{E}}$ ECENTLY, it has been demonstrated that intravenous administration of octanoate, an 8-carbon free fatty acid, in healthy dogs increases the concentration of plasma insulin and decreases the concentration of plasma glucose as a result of a prompt fall in rate of glucose production by the liver. ${ }^{1-4}$ It has also been shown that in totally pancreatectomized dogs octanoate infusion produces minimal, if any, alteration in plasma glucose concentration. ${ }^{4}$ These findings have suggested that the hypoglycemic action of octanoate is mediated by increased release of endogenous insulin. Since the liver is capable of converting octanoate to ketone bodies, ${ }^{5}$ the increase in insulin release could be due to either a direct action of octanoate on the pancreas or an indirect one mediated by its metabolites, the ketone bodies. ${ }^{6}$ The following study was designed specifically to determine whether or not octanoate could stimulate release of insulin by the isolated rat pancreas.

\section{Materials and Methods}

A modification ${ }^{\top}$ of the technic of Coore and Randle ${ }^{8}$ was used in this study. After an overnight fast, 23 male Wistar albino rats, each weighing approximately $200 \mathrm{Gm}$., were decapitated and the pancreas excised immediately. From each pancreas one piece of tissue was sliced. weighing between 100 and $150 \mathrm{mg}$., and was successively incubated as follows:

Incubation Period 1. For purpose of stabilization the pancreatic tissue slices were first incubated at $37 \mathrm{C}$ for 20 minutes in flasks containing $3 \mathrm{ml}$. Krebs-bicarbonate buffer at $\mathrm{pH} 7.2$ and with a glucose concentration of $0.6 \mathrm{mg} . / \mathrm{ml}$. The environment inside the closed flasks was continuously gassed with 95 per cent oxygen and 5 per cent carbon dioxide during this and both subscquent incubation periods.

Incubation Period 2. Each of the 23 pieces of pancreas were then transferred to separate

From the Department of Internal Medicine, University of Michigan, Ann Arbor, Michigan and The Research Institute, The Hospital for Sick Children, Toronto, Canada.

This investigation was supported in part by the Medical Research Council of Canada, Grant $M T-1202$.

Received for publication Dec. 1, 1966.

Shafeer S. SANBar, M.D., Ph.D.: Instructor, Department of Internal Medicine, University of Michigan, Ann Arbor, Mich. Julto M. Martin, M.D.: Research Associate, The Research Institute, The Hospital for Sick Children, Toronto, Canada. 
Table 1.-Mean \pm I S.E. Insulin Release by Isolated Rat Pancreas during Two 15-minutes Successive Incubation Periods

\begin{tabular}{|c|c|c|c|c|}
\hline \multirow{2}{*}{$\begin{array}{c}\text { No. of } \\
\text { Observations }\end{array}$} & \multirow{2}{*}{$\begin{array}{l}\text { Incubation Medium } \\
\text { in Period } 3\end{array}$} & \multicolumn{2}{|c|}{ Insulin Release during } & \multirow{2}{*}{$\begin{array}{l}\text { Difference } \\
\text { (p-value) }\end{array}$} \\
\hline & & Period 2 & Period 3 & \\
\hline & & \multicolumn{3}{|c|}{$\mu \mathrm{U}$. insulin $/ \mathrm{mg}$. pancreatic tissue } \\
\hline 7 & Glucose $0.6 \mathrm{mg} . / \mathrm{ml}$. & $\begin{array}{r}5.22 \\
\pm .45\end{array}$ & $\begin{array}{r}5.53 \\
\pm .92\end{array}$ & $\begin{array}{c}0.31 \\
(>.05)\end{array}$ \\
\hline 10 & $\begin{array}{l}\text { Glucose } 0.6 \mathrm{mg} . / \mathrm{ml} \text {. } \\
\text { Octanoate } 3 \mathrm{mM} \text {. }\end{array}$ & $\begin{array}{r}6.50 \\
\pm .41\end{array}$ & $\begin{array}{r}11.44 \\
\pm 1.11\end{array}$ & $\begin{array}{l}4.94 \\
(<.001)\end{array}$ \\
\hline 6 & Glucose $3 \mathrm{mg} . / \mathrm{ml}$ & $\begin{array}{r}5.47 \\
\pm .59\end{array}$ & $\begin{array}{r}8.13 \\
\pm 1.30\end{array}$ & $\begin{array}{c}2.96 \\
(<.05)\end{array}$ \\
\hline
\end{tabular}

flasks containing $3 \mathrm{ml}$. of the same incubation medium as in Period 1 and incubated for 15 minutes. This was considered a control period.

Incubation Period 3. Finally, the pancreatic slices were again transferred to flasks containing $3 \mathrm{ml}$. of the following incubation media: (a) 7 pieces were placed in flasks containing the same incubation medium as in Periods 1 and 2, (b) 10 pieces were placed in the above incubation medium to which $3 \mathrm{mM}$. sodium octanoate was added, (c) and 6 pieces were placed in the above incubation medium but with a glucose concentration of $3 \mathrm{mg} . / \mathrm{ml}$. and without octanoate. After 15 minutes of incubation, they were removed from the flasks and discarded.

The total amounts of insulin released into the incubation media during Periods 2 and 3 were measured by the immunoassay of Herbert et al. ${ }^{9}$ Results were expressed as $\mu \mathrm{U}$. insulin/ $\mathrm{mg}$. wet weight of pancreatic tissue used per 15 minutes of incubation.

\section{Results}

It is noted in Table 1 that insulin release during the control incubation (Period 2) averaged between 5.22 and $6.50 \mu \mathrm{U}$. insulin/mg. of pancreatic tissue; the differences among the 3 "subgroups" were not statistically significant $(p>.05)$. It is also noted in the first subgroup that insulin release was unaltered during incubation Period 3 where the incubation medium was the same as the control. On the other hand, addition of $3 \mathrm{mM}$ octanoate to the incubation medium in Period 3 produced a highly significant increase in insulin release, which was slightly greater than that produced by $3 \mathrm{mg}$. glucose $/ \mathrm{ml}$. incubation medium in the absence of octanoate.

\section{Discussion}

These data clearly show that the free fatty acid octanoate is capable of directly stimulating the beta-cells of the pancreas in vitro to release additional insulin. This finding strongly suggests that the hypoglycemic action of octanoate, reported previously, ${ }^{1-4}$ results at least partly from direct stimulation by octanoate of endogenous insulin secretion. It is, of course, possible that the metabolites of octanoate, the ketone bodies, ${ }^{5}$ may also play some role in enhancing the secretion of insulin, ${ }^{6}$ although Randle ${ }^{10}$ was unable to obtain any response from rabbit pancreas incubated with $\beta$-hydroxybutyrate. Finally, it is noteworthy that the effect of $3 \mathrm{mM}$. octanoate on the isolated rat pancreas is 
comparably greater than that produced by $3 \mathrm{mg}$. glucose $/ \mathrm{ml}$. of incubation medium. It is concluded that the free fatty acid octanoate can now be included among those substances which are capable of directly stimulating the hetacells of the pancreas.

\section{REFERENCES}

1. Sanbar, S. S., Evans, J. R., and Forbath, N.: In vivo effect of fatty acid on glucose metabolism (abstract). Fed. Proc. 24:438, 1965.

2. - Hetenyi, G., Jr., Forbath, N., and Evans, J. R.: Eflects of infusion of octanoate on glucose concentration and rates of glucose production and utilization in dogs. Metabolism 14: $1311,1965$.

3. —, -, - , Lin, B., and Evans, J. R.: Influence of free fatty acid (FFA) on glucose metabolism in vivo and in vitro (abstract). Circulation 32:III-29, 1965.

4. - Evans, J. R., Lin, B., and Hetenyi, G., Jr.: Further studies on the effect of octanoate on glucose metabolism in dogs. Canad. J. Physiol. Pharm. 45: 66, 1967.

5. Werk, E. E., Jr., McPherson, H. T., Hamrick, L. W., Jr., Myers, J. D., and Engle, F. L.: Studies on ketone metabolism in man. I. A method for quantitative estimation of splanchnic ketone production. J. Clin. Invest. 34:1256, 1955.

6. Madison, L. L., Mebane, D., Unger, R. H., and Lochner, A.: The hypoglycemic action of ketones. II. Evidence for a stimulatory feedback of ketones on the pancreatic beta cells. J. Clin. Invest. 43:408, 1964.

7. Martin, J. M., and Bambers, G.: Insulin Secretion in glucosamine-induced hyperglycemia in rats. Amer. J. Physiol. 209:797, 1965.

8. Coore, H. G., and Randle, P. J.: Regulation of insulin secretion studied with pieces of rabbit pancreas incubated in vitro. Biochem. J. 93:66, 1964.

9. Herbert, V., Lau, K-S., Gottlieb, C. W., and Bleicher, S. J.: Coated charcoal immunoassay of insulin. J. Clin. Endocrinol. 25:1375, 1965.

10. Randle, P. J.: Rate of release of insulin in vitro: Ciba Found. Coll. Endocrinol. 15:107, 1964. 